\title{
Znaczenie dystansu w procesie internacjonalizacji przedsiębiorstw
}

Nadesłany: 09.08.12

Zaakceptowany do druku: 01.10.12

\section{Dr Mariola Ciszewska-Mlinarič | Akademia Leona Koźmińskiego | mariolac@kozminski.edu.pl Dr Aleksandra Wąsowska | Uniwersytet Warszawski | awasowska@mail.wz.uw.edu.pl}

\begin{abstract}
Abstrakt
Cel: Celem artykułu jest ukazanie wielowymiarowości pojęcia dystansu oraz podsumowanie aktualnego stanu badań na temat znaczenia dystansu w procesie umiędzynarodowienia przedsiębiorstw.
\end{abstract}

Metodologia: Przegląd literatury, przeprowadzony na podstawie baz artykułów naukowych (EBSCO, Elsevier, JSTOR, ProQuest), objął artykuły z dziedziny internacjonalizacji, które w tytule lub abstrakcie miały słowo „dystans” i jednocześnie prezentowały wyniki badań dotyczących zależności między dystanesem a kluczowymi zagadnieniami internacjonalizacji przedsiębiorstw. Prezentacja wyników została zorganizowana wokół pięciu głównych wymiarów dystansu: geograficznego, ekonomicznego, instytucjonalnego, kulturowego oraz psychicznego. Ten ostatni stanowi wypadkową czterech pozostałych i odnosi się do percepcji różnic między krajami.

Wnioski: Rozwój nowych form transportu i technologii komunikacji oraz postępująca integracja gospodarcza sprawiają, że zdaniem wielu autorów i praktyków dystans przestaje być istotną kategorią w opisie umiędzynarodowienia przedsiębiorstw. To przekonanie jest jednak podważane przez wyniki badań empirycznych.

Implikacje badawcze: Wielowymiarowość pojęcia dystansu oraz wysoka niejednoznaczność wyników prac empirycznych poświęconych wymiarowi kulturowemu tworzą nowe wyzwania badawcze. W artykule sformułowano rekomendacje dla badaczy zainteresowanych problematyką dystansu w biznesie międzynarodowym.

Oryginalność: Autorki przedstawiają obszerny przegląd badań, ukazując wpływ poszczególnych wymiarów dystansu na kluczowe zagadnienia internacjonalizacji przedsiębiorstw, tj. motywy, wybór rynku i sposobu umiędzynarodowienia oraz poziom lokalnej adaptacji i globalnej integracji. W przeglądzie dokonano wyraźnego rozróżnienia pomiędzy dystansem psychicznym i dystansem mierzonym na poziomie różnic między krajami.

Słowa kluczowe: dystans geograficzny, ekonomiczny, instytucjonalny, kulturowy, psychiczny 


\title{
Significance of distance in the internationalisation process of firms
}

Primary submission: 09.08.12

Final acceptance: 01.10 .12

\begin{abstract}
Purpose: The purpose of the article is to discuss the multidimensionality of the distance construct and to provide a critical overview of the existing research on distance and its significance for the internationalization process.

Methodology: The review of relevant literature, based on databases such as EBSCO, Elsevier, JSTOR and ProQuest, covered empirical papers (keyword: "distance" included in the title or abstract) investigating the relationship between the distance and key issues in the companies' internationalization. The presentation of results was structured along five key dimensions of distance: geographic, economic, institutional, cultural and psychic. The first four dimensions are antecedents to psychic distance, which itself relates to the managerial perception of differences between the countries.
\end{abstract}

Findings: The development of new forms of transportation and communication technologies, together with the increasing economic integration, have made many authors and managers believe that distance is no longer relevant to the companies' internationalization process. However, the empirical studies do not confirm this claim.

Research implications: The multidimensionality of distance and inconsistencies in the body of research concerning the cultural dimension of distance create new research challenges. The present article provides recommendations for the scholars interested in the role of distance in international business.

Originality: The article presents an extensive literature review, explicitly indicating the role of different dimensions of distance in key internationalization issues, i.e. motives, market selection, mode of entry, level of local responsiveness and global integration. It makes a clear distinction between psychic distance and country-level distance.

Keywords: geographic, economic, institutional, cultural, psychic distance

$$
\text { JEL: F18, F23 }
$$




\section{Wprowadzenie}

Pojęcie dystansu oraz związane z nim założenie, że lokalizacja ma wpływ na charakter transakcji biznesowych (Brock et al. 2011) stanowią podstawę teorii handlu zagranicznego i biznesu międzynarodowego (ang. International Business, dalej IB). W grawitacyjnych modelach handlu zagranicznego (ang. gravity models), budowanych na poziomie makro, kluczową zmienną determinującą wartość wymiany handlowej między dwoma krajami jest dystans geograficzny (Tinbergen 1962). Teorie opisujące umiędzynarodowienie przedsiębiorstw, rozwijane na poziomie mikro, opierają się na założeniu, że barierą dla internacjonalizacji jest obcość danego rynku i związane z nią dodatkowe koszty prowadzenia działalności za granicą (ang. liability of foreignness) (Hymer 1976). Źródłem tych kosztów są np. nieznajomość rynku, bariery językowe oraz brak orientacji w systemie polityczno-prawnym. Zgodnie z etapowym modelem uppsalskim firmy rozpoczynają ekspansję od rynków najbliższych macierzystemu, przesuwając się, wraz ze wzrostem doświadczenia za granicą, ku rynkom coraz bardziej odległym (Johanson, Vahlne 1977).

Wraz z rozwojem nowych form transportu oraz technologii komunikacji integracja międzynarodowa pogłębia się, a znaczenie dystansu jako podstawowej bariery utrudniającej ten proces wydaje się tracić na znaczeniu. Hamill (1997) zauważył na przykład, że popularyzacja Internetu, narzędzia niewrażliwego na lokalizację, sprawia, że analiza umiędzynarodowienia jako procesu pokonywania dystansu przestaje mieć sens. Cairncross (1997), idąc o krok dalej, ogłosiła „śmierć dystansu", wynikającą z rozwoju technologii komunikacyjnych. W swojej popularnej książce Świat jest płaski Friedman (2006) wśród sił, które prowadzą do zaniku dystansu i spłaszczenia świata, wymienił, oprócz Internetu, zmiany konfiguracji łańcucha wartości, m.in. outsourcing, offshoring, supply-chaining (budowanie przewagi konkurencyjnej na podstawie szybkiego i niezawodnego łańcucha dostaw) oraz technologie zarządzania przepływem pracy.

Teoretycy biznesu międzynarodowego podkreślają, że menedżerowie firm mają skłonność do przeceniania atrakcyjności rynków zagranicznych (Ghemawat 2001; Khanna, Palepu 2010). Wynika to ze stosowania narzędzi analitycznych, które nie uwzględniają różnic między rynkiem macierzystym a krajem potencjalnego zaangażowania. Przykładowo, popularna analiza CPA (ang. country portfolio analysis), która na bazie m.in. poziomu PKB i skłonności do konsumpcji szacuje chłonność danego rynku, pomija kwestię kulturowej i administracyjnej dostępności rynku dla konkretnej firmy. Liczne przykłady nieudanych prób ekspansji korporacji międzynarodowych na kolejne rynki (np. Ebay w Chinach, Wal-Mart w Niemczech, Home Depot w Chile, Starbucks w Australii) pozwalają przypuszczać, że niedocenianie roli dystansu może prowadzić do błędnych decyzji menedżerskich, związanych np. z wyborem rynku, sposobem wejścia czy strategią działania na rynku zagranicznym.

Popularne w publicystyce oraz stosunkowo częste wśród menedżerów przekonanie o zanikaniu dystansu (zarówno geograficznego, jak i kulturowego) między krajami jest jednak podważane przez wyniki badań empirycznych. Frankey i Rose (2002) dowiedli, że wspólna granica zwiększa handel między dwoma krajami o 80\%, wspólny język - o 200\%, wspólna waluta - o 340\%, 
a więzi kolonialne w przeszłości - o 900\%. Rugman (2005), analizując kierunki sprzedaży oraz lokalizacji aktywów firm należących do listy 500 największych przedsiębiorstw publikowanej przez magazyn Fortune, zauważył, że zdecydowana większość tych firm nie działa w skali globalnej, lecz regionalnej.

Celem niniejszego artykułu jest ukazanie wielowymiarowości pojęcia dystansu, podsumowanie aktualnego stanu wiedzy na temat znaczenia dystansu w biznesie międzynarodowym oraz sformułowanie rekomendacji dla badaczy zainteresowanych tematyką dystansu. W dalszej części zostaną przedstawione cztery główne wymiary dystansu na poziomie różnic między państwami: wymiar geograficzny, kulturowy, instytucjonalny, ekonomiczny. Ponadto omówiony zostanie dystans psychiczny, który stanowi wypadkową czterech pozostałych i dotyczy percepcji dystansu przez menedżerów.

\section{Wielowymiarowość pojęcia dystansu w biznesie międzynarodowym}

W literaturze z zakresu IB pojęcie dystansu odnosi się do różnic między krajami/narodami, których zakres może dotyczyć wielu obszarów, w zależności od podejścia teoretycznego oraz przyjętej metody badawczej. Przykładowo, Johanson i Vahlne (1977: 24) wskazywali na różnice ,języka, systemów edukacji, praktyk biznesowych, kultury i poziomu rozwoju przemysłowego". Kogut i Singh (1988) analizowali różnice dotyczące cech rynku zagranicznego, mierzone za pomocą wymiarów kultury narodowej w ujęciu Hofstede. Barkema, Bell i Pennings (1996: 153) wymieniali czynniki ,językowe, instytucjonalne, kulturowe i polityczne”, lecz konstrukt dystansu sprowadzili następnie do różnic kulturowych. Uznając wielowymiarowść pojęcia dystansu, badacze koncentrowali się jednak na jego jednym - kulturowym - wymiarze.

Pierwsza wielowymiarowa typologia dystansu znana w literaturze jako model CAGE, została sformułowana przez Ghemawata (2001). Nazwa modelu jest anglojęzycznym akronimem od słów: kulturowy (ang. cultural), administracyjny (ang. administrative), geograficzny (ang. geographic) oraz ekonomiczny (ang. economic). Berry et al. (2010) rozszerzyli typologię Ghemawata o pięć dodatkowych wymiarów: finansowy (poziom rozwoju rynków finansowych), polityczny (stabilność polityczna, poziom demokracji), demograficzny (struktura demograficzna społeczeństwa), komunikacyjny (turystyka i dostęp do Internetu) oraz związany z wiedzą (patenty i poziom wiedzy naukowej). Ze względu na fakt, iż trzy z tych wymiarów można traktować jako uszczegółowienie typologii Ghemawata (wymiar finansowy oraz związany z wiedzą versus ekonomiczny; polityczny versus administracyjny), a pozostałe dwa (demograficzny i komunikacyjny) były jedynie w niewielkim stopniu wykorzystywane w pracach empirycznych (Berry et al. 2010), w dalszej części artykułu zaprezentowane zostaną cztery podstawowe wymiary dystansu (Ghemawat 2001). Dodatkowo w przeglądzie literatury zostanie uwzględniony konstrukt dystansu psychicznego, odwołujący się do dystansu postrzeganego przez menedżerów. Definicje wymiarów dystansu podsumowano w tabeli 1. 
Tabela 1 | Wymiary dystansu

\begin{tabular}{|c|c|}
\hline Wymiary dystansu & Definicja / czynniki składowe \\
\hline Dystans geograficzny & $\begin{array}{l}\text { - Odległość, brak wspólnej granicy, różne strefy czasowe, różnice klimatu/chorób panujących w danym regionie } \\
\text { (Ghemawat 2001). } \\
\text { - Ortodroma (najkrótsza odległość) pomiędzy geograficznymi środkami krajów (Berry et al. 2010) }\end{array}$ \\
\hline Dystans ekonomiczny & $\begin{array}{l}\text { - Różnice w poziomie dochodu mieszkańców; róznice dotyczące kosztów i jakości: zasobów naturalnych, finansowych, } \\
\text { ludzkich, infrastruktury, surowców pośrednich, wiedzy i informacji (Ghemawat 2001). } \\
\text { - Różnice w poziomie rozwoju gospodarczego i wskaźników makroekonomicznych (Berry et al. 2010) }\end{array}$ \\
\hline Dystans instytucjonalny & $\begin{array}{l}\text { - Brak więzi kolonialnych, brak uczestnictwa we wspólnocie gospodarczej, brak wspólnej waluty, wrogość polityczna* } \\
\text { (Ghemawat 2001). } \\
\text { - Róźnice dotyczące obszaru regulacyjnego (zbiór regulacji prawnych oraz sposób i stopień ich przestrzegania), } \\
\text { poznawczego (schematy i stereotypy) oraz normatywnego (przekonania, normy i wartości) (Kostova, Zaheer 1999) }\end{array}$ \\
\hline Dystans kulturowy & $\begin{array}{l}\text { - Różne języki, grupy narodowościowe, religie, normy społeczne, brak zaufania (Ghemawat 2001). } \\
\text { - Różnice w zakresie stosunku do władzy, zaufania, indywidualizmu oraz znaczenia pracy i rodziny (Berry et al. 2010) }\end{array}$ \\
\hline Dystans psychiczny & $\begin{array}{l}\text { - Postrzegane koszty uczenia się lub redukcji niepewności, wynikające z „różnic dotyczących języka, systemów } \\
\text { edukacji, praktyk biznesowych, kultury oraz poziomu rozwoju przemysłu” (Johanson, Vahlne 1977). }\end{array}$ \\
\hline
\end{tabular}

\section{Dystans geograficzny}

Decyzja o umiędzynarodowieniu poprzedzona jest zwykle analizą korzyści i kosztów działania na danym rynku. W literaturze na temat handlu zagranicznego koszty ekspansji zagranicznej tradycyjnie są rozumiane jako pochodna sztucznie tworzonych barier handlowych (taryfowe i pozatryfowe), będących efektem określonej polityki gospodarczej, oraz barier naturalnych, takich jak czas i koszt przesyłki, związanych z pokonywaniem dystansu geograficznego (Hummels 2007). Ten ostatni wpływa na handel zagraniczny, podnosząc koszty transportu i komunikacji (Ghemawat 2001) oraz powodując ewentualną utratę wartości transportowanych produktów (Clark et al. 2004).

Wysokość taryfowych i pozataryfowych barier handlowych w gospodarce światowej osiągnęła najwyższy poziom w połowie XX wieku i od tego czasu stopniowo spada. Oznacza to, że w ostatnich kilkudziesięciu latach wzrosło relatywne znaczenie barier naturalnych w wyborze kierunku umiędzynarodowienia.

Jak zauważa Hummels (2007), koszty transportu są obecnie wyższe i bardziej zróżnicowane w zależności od strategii eksportera (będącej pochodną struktury geograficznej sprzedaży i typu sprzedawanych dóbr) niż koszty opłat taryfowych i ceł. Około 1/4 światowego handlu odbywa się między krajami dzielącymi granicę lądową, a połowa - między partnerami oddalonymi od siebie o mniej niż 3000 kilometrów. Zdecydowana większość handlu między krajami sąsiadującymi ze 
sobą odbywa się drogą lądową (transport samochodowy, kolejowy, rurociągowy), a jedynie 10\% drogą morską lub lotniczą.

Na podstawie analizy kosztów transportu z Baltimore Linmao i Venebles (2001) dowiedli, że 10-procentowy wzrost kosztów transportu ogranicza handel o 20\%. Frankel i Rose (2002) wykazali, że wielkość handlu między dwoma krajami spada o ok. 1\% wraz z każdym procentem wzrostu dystansu geograficznego między nimi. Hummels (2001) obliczył, że w przypadku dóbr przemysłowych wydłużenie czasu transportu oceanicznego o jeden dzień obniża prawdopodobieństwo handlu między dwoma krajami o 1,5\%.

Znaczenie dystansu geograficznego podkreślane jest w popularnych w ekonomii modelach grawitacji (ang. gravity models), służących szacowaniu wartości dwustronnej wymiany handlowej. Modele te inspirowane są prawem powszechnego ciążenia sformułowanym przez Newtona, zgodnie z którym siła przyciągania między dwoma obiektami jest wprost proporcjonalna do iloczynu ich mas i odwrotnie proporcjonalna do kwadratu dzielącej je odległości. Pierwszej aplikacji modeli grawitacyjnych na gruncie ekonomii dokonał Tinbergen (1962). W swojej podstawowej postaci model grawitacji zakłada, że wielkość wymiany handlowej między dwoma krajami jest dodatnią funkcją wielkości ich gospodarek i ujemną funkcją dzielącego je dystansu geograficznego. Bardziej rozbudowane modele uwzględniają dodatkowe zmienne, takie jak dochody na głowę mieszkańca czy obecność preferencyjnych porozumień handlowych (Cieślik 2007). Generalnym wnioskiem płynącym z analizy modeli grawitacji jest stwierdzenie, że duże i wysoko rozwinięte kraje handlują ze sobą więcej niż kraje małe i słabo rozwinięte oraz że większość handlu odbywa się pomiędzy krajami położonymi w niewielkiej odległości od siebie (Cieślik 2007).

O ile dystans geograficzny wydaje się jednoznaczną barierą w procesie umiędzynarodowienia $\mathrm{w}$ formie eksportu, o tyle jego wpływ na bezpośrednie inwestycje zagraniczne (dalej: BIZ) nie jest oczywisty. Z jednej strony, w warunkach dużego dystansu geograficznego, BIZ mogą być traktowane jako alternatywa dla eksportu, pozwalająca na redukcję kosztów transportu (Lankhuizen et al. 2011). Tym samym można byłoby oczekiwać pozytywnej zależności między dystansem geograficznym a wielkością BIZ. Z drugiej strony, dystans geograficzny podnosi koszty administracyjne (związane np. z monitorowaniem działalności filii), a tym samym może negatywnie wpływać na wielkość BIZ. Badania wykazują generalnie negatywną zależność między dystansem geograficznym a BIZ (Carr et al. 2001), co wskazuje na poprawność drugiej hipotezy.

Liczne badania z zakresu BM dowodziły, że istnieje wpływ dystansu geograficznego na decyzje związane z wyborem rynku docelowego. Clark i Pugh (2001), badając firmy brytyjskie, wykazali, że pierwsze trzy rynki wybierane w procesie umiędzynarodowienia są bliższe krajowi pochodzenia firmy niż rynki czwarty, piąty i kolejne. Autorzy badania tłumaczyli to zjawisko niższymi kosztami zarządzania w krajach o niewielkim dystansie geograficznym. Dow (2000) zauważył, że australijskie małe i średnie firmy preferują kraje bliskie geograficznie ze względu na niższe koszty transportu. Podobnie Chetty (1999) dowiodła, że preferowanym kierunkiem umiędzynarodowienia małych i średnich firm z Nowej Zelandii jest Australia. Ojala i Tyrväinen (2007) 
w badaniu fińskich małych i średnich przedsiębiorstw z branży software wykazali, że głównymi determinantami wyboru rynku docelowego były wielkość rynku i dystans geograficzny, natomiast dystans kulturowy okazał się nieistotny.

W badaniu amerykańskich agencji reklamowych Terpstra i Yu (1988) wykazali z kolei, że dla badanych przez nich amerykańskich agencji reklamowych większe znaczenie miała wielkość rynku niż dystans geograficzny. Wpływ dystansu geograficznego na wybór kierunku umiędzynarodowienia może zatem zależeć od branży i, jak sugeruje Ghemawat (2001), być szczególnie istotny w przypadku produktów o niskim stosunku wartości do wagi (ang. value-to-weight ratio) lub których produkcja wymaga intensywnej koordynacji między rozproszonymi działaniami.

Pojęcie dystansu geograficznego odnosi się nie tylko do odległości między dwoma krajami mierzonej w kilometrach. Szacując dystans geograficzny jako barierę dla umiędzynarodowienia, należy wziąć pod uwagę np. powierzchnię kraju, średnią wewnątrzkrajową odległość do granicy, topografię, dostęp do morza, infrastrukturę transportową i komunikacyjną (Ghemawat 2001). Boeh i Beamish (2012) wykazali, że wpływ na wybór kierunku i sposobu umiędzynarodowienia ma nie tyle dystans mierzony w kilometrach, ile czas podróży między centralą a filią zagraniczną. Długi czas podróży zwiększa koszty monitorowania działalności, dlatego wybierając kierunek umiędzynarodowienia, firmy preferują kraje, do których dojazd zajmuje niewiele czasu. W przypadku lokalizacji wymagających długiego czasu podróży preferowanym sposobem umiędzynarodowienia są wspólne przedsięwzięcia, pozwalające obniżyć koszty monitorowania działalności za granicą.

\section{| Dystans ekonomiczny}

Kolejny z wymienionych przez Ghemawata (2001) wymiarów dystansu odnosi się do różnic poziomów rozwoju gospodarczego krajów, odzwierciedlonych w kosztach czynników produkcji (szczególnie wysokości płac) oraz dostępności zasobów technologicznych.

Na znaczenie dystansu ekonomicznego dla struktury handlu zagranicznego zwrócił uwagę Vernon (1966), autor teorii cyklu życia produktu. Punktem wyjścia do jego rozważań była koncepcja luki technologicznej (Posner 1971), zgodnie z którą eksporterami innowacyjnych produktów są kraje mające przewagę technologiczną. Vernon zauważył jednak, że początkowa przewaga konkurencyjna, oparta na zdolnościach technologicznych, traci z czasem na znaczeniu. W miarę upowszechniania się produktu popyt staje się bardziej elastyczny, a zatem coraz większą rolę w budowaniu przewagi konkurencyjnej odgrywają czynniki kosztowe. Produkcję rozpoczynają firmy z krajów mniej zaawansowanych technologicznie, sprzedając produkt na swoich rynkach lokalnych. Jednocześnie, chcąc utrzymać przewagę konkurencyjną, innowatorzy przenoszą produkcję do krajów o niższych kosztach pracy, konkurując z firmami lokalnymi. W ostatniej fazie produkty wytwarzane przez filie zlokalizowane w krajach o niższych kosztach produkcji importowane są do krajów macierzystych. 
Teoria cyklu życia produktu powstała w latach 60. XX wieku, kiedy źródłem innowacji były głównie kraje wysoko rozwinięte, w tym przede wszystkim Stany Zjednoczone. Wzrost znaczenia rynków wschodzących w globalnej gospodarce sprawia, że tradycyjny model innowacji produktowych staje się niewystarczający. Na rynkach dołu piramidy żyje ok. 5 miliardów ludzi, kraje takie jak Chiny i Indie charakteryzuje wysokie tempo wzrostu gospodarczego (w przeciwieństwie do państw rozwiniętych), a firmy z rynków wschodzących (np. chiński Haier) stają się coraz bardziej widoczne w globalnej gospodarce. Aby sprostać konkurencji ze strony wschodzących gigantów (ang. emerging giants) oraz budować pozycje na rynkach wschodzących, firmy takie jak General Electric (GE) muszą stać się bardziej innowacyjne (Immelt et al. 2009). Jedna z najważniejszych inicjatyw podjętych w ostatnich latach przez GE to „odwrotna innowacja” (ang. reverse innovation). W ujęciu historycznym GE, podobnie jak wiele innych firm międzynarodowych, koncentrowało się na tworzeniu innowacyjnych produktów w krajach wysoko rozwiniętych, a następnie wprowadzało te produkty na rynki wschodzące. Zazwyczaj sprzedaż tych produktów była niska, ponieważ większość z nich nie spełniała ani oczekiwań cenowych, ani specyficznych potrzeb lokalnych odbiorców. W przeciwieństwie do tego podejścia program „odwrotnej innowacji” zakłada tworzenie innowacyjnych produktów na potrzeby rynków wschodzących, a następnie wprowadzenie ich na rynki wysoko rozwinięte jako konkurencyjną cenowo ofertę. Przykładowo: tradycyjne ultrasonografy (w cenie między 100-350 tys. USD) były zbyt kosztowne dla chińskich szpitali w obszarach wiejskich, z których korzysta ok. 90\% populacji. Przeprowadzenie badania wymagało transportu chorych do szpitali miejskich i w praktyce często nie było wykonywane. W 2002 roku lokalny zespół GE wprowadził tanie, przenośne urządzenie ultrasonograficzne (ok. 30-40 tys. USD), a w 2008 jego kolejny model w cenie 15 tys. USD. Ta innowacja wdrożona została następnie nie tylko w Chinach, lecz na całym świecie, włączajac kraje wysoko rozwinięte (gdzie m.in. znajduje zastosowanie $\mathrm{w}$ ratownictwie medycznym).

W literaturze istnieje stosunkowo niewiele badań nawiązujących bezpośrednio do pojęcia dystansu ekonomicznego i jego znaczenia w procesie umiędzynarodowienia przedsiębiorstw. Do nielicznych prac na ten temat należy badanie Makino et al. (2002), dotyczące motywów ekspansji zagranicznej. Autorzy zadają pytanie o to, co sprawia, że firmy decydują się na inwestycje w krajach mniej rozwiniętych, a jakie czynniki motywują je do ekspansji na bardziej konkurencyjne rynki krajów wyżej rozwiniętych. Badanie przeprowadzone na spółkach tajwańskich, a więc w szczególnych warunkach gospodarki nowo uprzemysłowionej, potwierdziło, że motywem ekspansji do krajów wyżej rozwiniętych jest poszukiwanie zasobów strategicznych, podczas gdy ekspansja zagraniczna do krajów niżej rozwiniętych wybierana była przez firmy szukające możliwości lewarowania własnych zasobów (w tym przypadku wiedzy) oraz dostępu do niższych kosztów pracy. Te dwa odmienne motywy prowadzenia bezpośrednich inwestycji zagranicznych odpowiadają eksploracji i eksploatacji zasobów w typologii Marcha (1991), dotyczącej uczenia się organizacji. Eksploracja polega na poszukiwaniu nowej wiedzy, w celu pozyskania korzyści w przyszłości, eksploatacja natomiast polega na wykorzystaniu wiedzy już istniejącej, w celu maksymalizacji korzyści bieżących. 
Badanie Makino et al. (2002) wykazało ponadto, że skłonność do poszukiwania zasobów w krajach wyżej rozwiniętych zależy od zdolności do absorbowania zasobów strategicznych, określonej przez dwie zmienne - wyposażenie w zasoby technologiczne oraz doświadczenie we współpracy z firmami z krajów wyżej rozwiniętych, zdobywanym poprzez licencjonowanie lub kontrakty typu OEM.

Bazując na wynikach uzyskanych przez Makino et al. (2002), Tsang i Yip (2007) badali efekty umiędzynarodowienia w zależności od dystansu ekonomicznego między krajem pochodzenia a krajem inwestycji. Badanie przeprowadzone na spółkach z Singapuru wykazało, że szanse powodzenia bezpośrednich inwestycji zagranicznych są wyższe, jeśli kraj goszczący cechuje się dużym dystansem ekonomicznym w stosunku do kraju pochodzenia. Interpretując ten wynik, autorzy badania zauważają, że o ile ekspansja zagraniczna do krajów o wyższym lub niższym poziomie rozwoju gospodarczego służy, odpowiednio, eksploracji i eksploatacji zasobów, o tyle inwestycje w krajach o podobnym poziomie rozwoju nie przynoszą tego rodzaju korzyści.

\section{Dystans instytucjonalny}

Podejście instytucjonalne, od lat 90. ubiegłego wieku obecne w literaturze z zakresu IB, podkreśla znaczenie instytucjonalnych „reguł gry”, w ramach których działają przedsiębiorstwa. Analizując wpływ instytucji na działania firm, Scott (1995) wskazuje na trzy obszary: regulacyjny, poznawczy i normatywny, nazwane przez niego „filarami podejścia instytucjonalnego”. Pierwszy z nich obejmuje zbiór regulacji prawnych, obowiązujących na danym rynku, a także sposób i stopień ich przestrzegania. Drugi dotyczy struktur poznawczych powszechnych dla danego społeczeństwa, m.in. schematów i stereotypów, którymi posługują się ludzie. Ostatni odnosi się do przekonań, wartości i norm, określających zestaw społecznie akceptowanych zachowań. Różnice dotyczące tych trzech obszarów składają się na dystans instytucjonalny między krajami (Kostova, Zaheer 1999).

Im większy jest dystans instytucjonalny, tym trudniejszy jest transfer zasad i praktyk biznesowych z centrali do filii zagranicznych. Jak wskazują Kostova i Zaheer (1999), w skrajnych warunkach transfer dotyczyć może samych formalnych reguł i nie obejmować leżących u ich podstaw wartości. W takich przypadkach przyjęcie danej praktyki przez filię może mieć jedynie charakter fasadowy. Czasami również dochodzi do „hybrydyzacji” praktyk filii i centrali, co zmienia funkcjonalność transferowanej przez centralę praktyki. Transfer praktyk jest ponadto przedmiotem negocjacji, w których menedżerowie filii, dzięki znajomości lokalnego otoczenia instytucjonalnego, mają często przewagę nad menedżerami centrali.

Badanie amerykańskich korporacji międzynarodowych wykazało, że próba transferowania praktyk wykorzystywanych w procesie rekrutacji, a szczególnie zasad zapewnienia zróżnicowania w środowisku pracy (ang. diversity), napotykała opór ze strony brytyjskich filii (Ferner et al. 
2005). Lokalni menedżerowie deklarowali przychylny stosunek do idei zróżnicowania, uważali jednak, że proponowany sposób jej egzekwowania, zakorzeniony w tradycji amerykańskiej, nie przystaje do warunków brytyjskich. Badanie wykazało ponadto, że menedżerowie filii, dzięki przypadającej im roli „tłumaczy” lokalnego otoczenia instytucjonalnego, umacniali swoją pozycję w negocjacjach z centralą odnośnie do transferu praktyk.

Aguilera-Caracuel et al. (2012) analizowali znaczenie dystansu instytucjonalnego w kontekście transferu praktyk i standardów dotyczących ochrony środowiska. Badanie przeprowadzone na zróżnicowanej sektorowo próbie korporacji międzynarodowych posiadających centrale i spółki zależne zlokalizowane w Stanach Zjednoczonych, Kanadzie, Meksyku, Francji i Hiszpanii wykazało, że duży dystans instytucjonalny (odnoszący się do różnic w zakresie regulacji środowiskowych obowiązujących w danym kraju) utrudnia transfer standardów dotyczących ochrony środowiska między centralą a filią.

Dystans instytucjonalny jest szczególnie istotny w przypadku korporacji zachodnich działających w gospodarkach wschodzących. Firmy te narażone są na ryzyko polityczne, w tym ryzyko korupcji, przerostu biurokracji, niestabilności politycznej i prawnej. Jak wskazują Khanna et al. (2005), firmy działające na rynkach wschodzących borykają się również z problemem „luk instytucjonalnych" (ang. institutional voids), związanych np. z brakiem ochrony praw własności, nieefektywną egzekucją prawa, słabo rozwiniętym rynkiem czynników produkcji.

Korporacje zachodnie jedynie w ograniczonym zakresie są w stanie wykorzystać na rynkach wschodzących przewagę konkurencyjną (np. markę, reputację, know-how) wypracowaną w kraju pochodzenia. Działanie w najwyższym, „globalnym” segmencie rynku nie wymaga najczęściej adaptacji produktu i polega na bezpośrednim przeniesieniu modelu biznesu z rynku macierzystego. Wejście na niższe segmenty rynku i skuteczne konkurowanie z obecnymi na nich lokalnymi graczami wymaga natomiast adaptacji modelu biznesu. Barierą dla adaptacji może być niewystarczająca znajomość otoczenia instytucjonalnego oraz obecność luk instytucjonalnych, np. brak niezależnych agencji badania rynku. Niezdolność do działania w warunkach próżni instytucjonalnej sprawia, że wiele firm z krajów wysoko rozwiniętych ogranicza swoją działalność na rynkach wschodzących do najwyższych segmentów rynku (Khanna, Palepu 2010).

W ostatnich latach pojęcie dystansu instytucjonalnego wykorzystywane było w analizie zagadnień wyjaśnianych do tej pory za pomocą dystansu kulturowego, takich jak np. sposoby wejścia na rynek zagraniczny. Badanie przeprowadzone na spółkach japońskich wykazało negatywną zależność między dystansem instytucjonalnym a udziałem kapitałowym centrali w filii zagranicznej (Ando 2012). Podobnie Xu (2001), badając firmy notowane na giełdzie w Tokio, wykazał, że w przypadku dużego dystansu instytucjonalnego firmy preferują umiędzynarodowienie w formie wspólnych przedsięwzięć (ang. joint ventures) oraz ograniczają własne zaangażowanie kapitałowe. Ponadto, dystans instytucjonalny jest negatywnie związany z poziomem globalnej integracji korporacji międzynarodowej. 
W badaniach ilościowych dystans instytucjonalny operacjonalizowany jest zwykle za pomocą wskaźników jakości rządzenia, opracowywanych przez Bank Światowy (World Bank Governance Indicators). Kaufmann et al. (2005) zidentyfikowali wśród nich sześć wymiarów opisujących otoczenie instytucjonalne: prawo wyrażania opinii i wpływ obywateli; polityczna stabilność i brak przemocy; efektywność administracji publicznej; jakość stanowionego prawa; rządy prawa; kontrola korupcji.

\section{Dystans kulturowy}

W odróżnieniu od ekonomistów, definiujących dystans między krajami przede wszystkim w kategoriach geograficzno-ekonomicznych, badacze reprezentujący dziedzinę nauk o zarządzaniu koncentrowali się na dystansie kulturowym (Ellis 2007). W badaniach analizowano na przykład zależności między dystansem kulturowym a wyborem rynku docelowego, sposobem wejścia na rynek zagraniczny oraz efektami umiędzynarodowienia (w tym wynikami finansowymi i czasem trwania międzynarodowych wspólnych przedsięwzięć.

Zgodnie z logiką teorii kosztów transakcyjnych (Williamson 1998) duży dystans kulturowy zwiększa koszty transakcyjne, utrudniając transfer zasobów i kompetencji oraz kontrolę nad działaniami za granicą (Buckley, Casson 1976). Można zatem przypuszczać, że wybierając kierunek umiędzynarodowienia firmy preferować będą kraje o niskim dystansie kulturowym oraz że dystans kulturowy będzie negatywnie związany z wynikami firm na rynkach zagranicznych. Można ponadto sformułować dwie alternatywne hipotezy odnośnie do wpływu dystansu kulturowego na wybór formy umiędzynarodowienia. Z jednej strony, dystans kulturowy może skłaniać firmy do wyboru kapitałowych form umiędzynarodowienia (w tym szczególnie samodzielnych inwestycji), zapewniających możliwie wysoki poziom kontroli nad operacjami zagranicznymi. Z drugiej strony, w warunkach wysokiego dystansu kulturowego firmy, którym brakuje doświadczenia na danym rynku, mogą być skłonne do współpracy z lokalnymi partnerami, np. w formie wspólnych przedsięwzięć.

Wyniki badań dotyczących zależności między dystansem kulturowym a wyborem rynku, sposobem wejścia na rynek zagraniczny oraz wynikami firm są niejednoznaczne. W badaniu dotyczącym wyboru rynku docelowego Robertson i Wood (2001) dowodzą, że otoczenie kulturowe jest w procesie decyzyjnym czynnikiem najmniej istotnym. Edwards i Buckley (1998) wykazują z kolei, że dla australijskich menedżerów bliskość kulturowa jest najważniejszym argumentem przemawiającym za wejściem na rynek brytyjski.

Padmanabhan i Cho (1996) wykazali, że w warunkach dużego dystansu kulturowego firmy umiędzynarodawiają swoją działalność w sposób zapewniający pełną kontrolę, tj. przez samodzielne spółki zależne. Brouthers i Brouthers (2001) uzyskali wynik odwrotny, wykazując, że w sytuacji dużego dystansu kulturowego firmy preferują umiędzynarodowienie w formie zapewniającej podział kontroli i ryzyka (np. wspólne przedsięwzięcie). Erramilli (1996) nie znalazł natomiast 
dowodów na zależność między dystansem kulturowym a preferowanym poziomem kontroli nad spółką zlokalizowaną za granicą.

Barkema, Bell i Pennings (1996) wykazali, że trwałość spółek lokalizowanych za granicą jest odwrotnie związana z dystansem kulturowym między danym rynkiem a krajem pochodzenia inwestycji. Podobnie Hennart i Zeng (2002), wykazali, że różnice kulturowe mają negatywny związek z długością trwania wspólnych przedsięwzięć. Morosini, Shane i Singh (1998) w badaniu dotyczącym akwizycji zagranicznych wskazali na pozytywną zależność między dystansem kulturowym a efektami akwizycji, mierzonymi wzrostem przychodów. Gomez-Mejia i Palich (1997) nie znaleźli natomiast zależności między dystansem kulturowym a wynikami finansowymi firm działających na rynkach zagranicznych.

W odróżnieniu od wyżej wymienionych badań istnieje jeden, wyraźny związek pomiędzy dystansem a kluczowymi zagadnieniami umiędzynarodowienia. Mianowicie wzrost dystansu kulturowego to jeden z czynników zwiększających presje na lokalną adaptację (ang. local responsiveness) (Bartlett, Ghoshal 1989). Moon i Park (2011) ukazali, że dystans kulturowy (mierzony na trzy sposoby) wiąże się z lokalną adaptacją strategii marketingowej w zakresie ceny, promocji i produktu.

Rozbieżności w uzyskiwanych wynikach tłumaczone były przede wszystkim trudnościami w pomiarze dystansu kulturowego. Zazwyczaj dystans kulturowy operacjonalizowany jest (Dow 2000; Sousa, Bradley 2006) przy pomocy indeksu Koguta i Singha (1988). Wskaźnik ten liczony jest jako średnia z różnic między dwoma krajami dla każdego z analizowanych wymiarów kultury narodowej. Oryginalny wskaźnik Koguta i Singha opierał się na czterech wymiarach kultury wskazanych przez Hofstede ${ }^{1}$, do których należą: dystans władzy, unikanie niepewności, męskość vs. kobiecość, unikanie niepewności². W późniejszych latach klasyfikacja Hofstede (2007) uzupełniona została o piąty wymiar - orientację długoterminową. W najnowszych badaniach wykorzystujących wskaźnik Koguta i Singha stosowana jest pełna klasyfikacja wymiarów kultury Hofstede (Dow, Karunaratna 2006). Indeks Koguta i Singha, podobnie jak sama klasyfikacja Hofstede (Boski 2009), ma szereg ograniczeń (Shenkar 2001), niemniej jednak pozostaje on najczęściej stosowaną w literaturze miarą dystansu kulturowego.

\section{| Dystans psychiczny}

Pojęcie dystansu psychicznego zostało wprowadzone do nauk ekonomicznych przez Beckermana (1956) w pracy dotyczącej transeuropejskich przepływów towarowych. Autor badania zauważył, że czynniki takie jak odległość geograficzna, koszt transportu czy wysokość cen nie są jedynymi

\footnotetext{
Omówienie wybranych typologii wymiarów kultury przedstawił Radosław Wolniak (2011).

2 W pionierskiej pracy na temat kultur narodowych Hofstede wykorzystał wewnętrzną bazę danych IBM, obejmującą 64 kraje, tworzoną w latach 1967-1973. Z uwagi na niedostępność danych, klasyfikacja Hofstede nie objęła krajów byłego bloku wschodniego, w tym Polski (Hofstede 2007).
} 
determinantami handlu między krajami. Istotną rolę odgrywa również dystans między krajami postrzegany przez menedżerów i przedsiębiorców, zależny np. od różnic językowych.

W latach 70. XX wieku badacze z Uniwersytetu w Uppsali wprowadzili pojęcie do nauk o zarządzaniu, wskazując na jego możliwe zastosowania w wyjaśnianiu wyboru rynków zagranicznych oraz form umiędzynarodowienia. Dystans psychiczny definiowano jako zbiór czynników zakłócających przepływ informacji między firmą i rynkiem (Johanson, Vahlne 1977) oraz utrudniających firmie uczenie się i rozumienie specyfiki rynku zagranicznego (Nordstron, Vahlne 1994) lub jako poziom postrzeganej niepewności związanej z funkcjonowaniem na rynkach zagranicznych, wynikającej z różnic kulturowych oraz innych czynników utrudniających uczenie się i działanie na danym rynku (O’Grady, Lane 1996). Dystans psychiczny rozumieć można zatem jako postrzegane koszty uczenia się lub redukcji niepewności, związanej z działaniem w warunkach „różnic dotyczących języka, systemów edukacji, praktyk biznesowych, kultury oraz poziomu rozwoju przemysłu" (Johanson, Vahlne 1977: 24).

W modelu etapowym (uppsalskim), bazującym na dorobku ekonomii behawioralnej (Simon 1947; Cyert, March 1963) podkreśla się, że proces umiędzynarodowienia firmy kształtowany jest nie tylko przez obiektywne czynniki ekonomiczne, ale także przez dostęp do informacji oraz mapy poznawcze decydentów. Dystans psychiczny ulega zmniejszeniu w miarę jak firma nabywa doświadczenia w działaniu na rynkach zagranicznych. Zakumulowana wiedza płynąca z doświadczenia stanowić może zasób wykorzystywany w procesie dalszej ekspansji zagranicznej. Wiedza o rynkach zagranicznych może mieć charakter „biznesowy” i dotyczyć znajomości klientów, konkurentów i warunków rynkowych w danym kraju. Drugim opisywanym w literaturze typem wiedzy płynącej z doświadczenia jest wiedza instytucjonalna polegająca na znajomości otoczenia instytucjonalnego oraz norm i wartości obowiązujących na danym rynku (Eriksson et al. 2000). Trzeci typ wiedzy stanowi umiejętność mobilizowania zasobów w procesie umiędzynarodowienia, utrwalona w procedurach organizacyjnych.

Klasyczny artykuł Johansona i Vahlne z 1977 roku, definiujący pojęcie dystansu psychicznego i stanowiący fundament etapowej teorii umiędzynarodowienia (model uppsalski), doczekał się prawie 2,5 tys. cytowań (baza Publish or Perish). Konstrukt ten wykorzystywany był przede wszystkim w badaniach dotyczących wyboru kierunku umiędzynarodowienia (por. Ellis 2007). Badania dotyczyły również m.in. transferu wiedzy w ramach korporacji międzynarodowej (Pedersen et al. 2003). Punktem wyjścia w tej grupie badań jest założenie, że im bardziej rynek zagraniczny różni się od kraju pochodzenia firmy, tym trudniej będzie firmie zbierać, analizować i poprawnie interpretować dane o rynku i tym większe będą obszary niepewności i trudności związane z prowadzeniem działalności za granicą. Przykładowo, w badaniu Pedersena i innych (2003), dystans psychiczny (mierzony za pomocą kwestionariusza) obniżał zdolność do transferowania wiedzy w ramach korporacji międzynarodowej.

Popularnym tematem badawczym była relacja między dystansem psychicznym a wynikami firm na rynkach zagranicznych. Wbrew oczekiwaniom teoretyków wyniki badań nie potwierdzają 
negatywnego wpływu dystansu psychicznego na wyniki firm (Ali 1995; Dikova 2009). Przeciwnie, istnieją badania sugerujące, iż wybór bliskich kulturowo krajów nie gwarantuje powodzenia w umiędzynarodowieniu (O’Grady, Lane 1996). Analiza wyników firm amerykańskich wchodzących na rynek kanadyjski dowiodła, że niedocenianie dystansu psychicznego między pozornie bliskimi kulturowo krajami może osłabiać wyniki umiędzynarodowionych przedsiębiorstw (O’Grady, Lane 1996). W pracy na temat inwestycji prowadzonych przez zachodnioeuropejskie korporacje międzynarodowe w krajach Europy Środkowo-Wschodniej Dikova (2009) sugeruje, że brak wiedzy o rynku zagranicznym motywuje firmy do lepszego przygotowania inwestycji i wzmacnia procesy uczenia. Z tego powodu dystans psychiczny może paradoksalnie sprzyjać osiąganiu lepszych wyników finansowych.

Dystans psychiczny nie jest tożsamy z dystansem kulturowym, choć w pracach empirycznych pojęcia te używane są czasami wymiennie (Dow, Karunaratna 2006) oraz mierzone w taki sam sposób, za pomocą indeksu Singha i Koguta. Po pierwsze, dystans psychiczny, w przeciwieństwie do kulturowego, opisuje różnice między krajami postrzegane przez menedżerów (Hakanson, Ambos 2010). „Psychiczny” pochodzi od greckiego słowa psyche, oznaczającego duszę lub umysł, i odnosi się do zjawisk zachodzących w umyśle jednostki. Oznacza to, że dystans psychiczny nie powinien być operacjonalizowany za pomocą wskaźników „obiektywnych”, takich jak poziom edukacji, język czy poziom PKB per capita. Metaanaliza przeprowadzona przez Zhao et al. (2004) wykazała, że konstrukt dystansu psychicznego mierzony na podstawie danych sondażowych, odwołujących się do percepcji menedżerskiej, był silniejszym predyktorem sposobu wejścia na rynek zagraniczny niż zmienne mierzone na podstawie danych wtórnych.

Po drugie, w oryginalnym rozumieniu szkoły uppsalskiej, dystans psychiczny dotyczy nie tylko kultury narodowej, ale także wielu innych wymiarów różnic między krajami. Do wymienianych w literaturze zestawów czynników składających się na dystans psychiczny należą: język, kultura, system polityczny, poziom edukacji, stopień rozwoju przemysłowego (Johanson, Wiedersheim-Paul 1975); religia, język, forma rządów, rozwój gospodarczy i poziom emigracji (Boyacigiller 1990); język, praktyki biznesowe, system polityczno-prawny, edukacja, rozwój gospodarczy, infrastruktura marketingowa, struktura przemysłu, kultura (Evans et al. 2000), kultura, język, poziom edukacji, rozwój przemysłowy, system polityczny, religia, strefa czasowa, powiązania kolonialne (Dow 2000). Jak zauważają Dow i Karunaratna (2006), czynniki mierzone na poziomie gospodarki traktować można jako determinanty dystansu psychicznego (ang. psychic distance stimuli), ponieważ mają one wpływ na postrzegane przez menedżerów różnice między krajami. Badania wykazują, że sam dystans kulturowy, mierzony za pomocą skali Hofstede, ma mniejszą moc wyjaśniania niż złożony konstrukt dystansu psychicznego (Dow 2000).

Hakanson i Ambos (2010) wykazali, że na dystans psychiczny wpływ mają następujące czynniki: dystans kulturowy, różnice językowe (w typologii Ghemawata również zaliczane do składowych dystansu kulturowego), dystans instytucjonalny, rywalizacja polityczna (składowa dystansu administracyjnego w typologii Ghemawata), dystans geograficzny, dystans ekonomiczny. Co 
ciekawe, najbardziej istotnym czynnikiem okazał się dystans geograficzny, którego rola w wyjaśnianiu dystansu psychicznego była ponadtrzykrotnie większa niż w przypadku dystansu kulturowego.

\section{Podsumowanie}

W niniejszym artykule zostały przedstawione główne wątki badawcze ukazujące wpływ różnych wymiarów dystansu na proces internacjonalizacji przedsiębiorstw. Powiązania między kluczowymi zagadnieniami internacjonalizacji (tj. motywami, wyborem kierunku i formy umiędzynarodowienia, wynikami oraz poziomem lokalnej adaptacji i globalnej integracji) a dystansem zostały podsumowane $\mathrm{w}$ tabeli 2 . W odniesieniu do dystansu psychicznego przegląd objął wyłącznie badania, w których dystans był operacjonalizowany na poziomie indywidualnym. Mając na względzie zachowanie poprawności metodologicznej przeglądu, pominięto badania, w których dystans psychiczny mierzony był za pomocą indeksu Koguta i Singha (1988).

Ograniczeniem powyższych analiz jest fakt, iż różne kategorie dystansu (szczególnie dystans instytucjonalny w wymiarze normatywnym i dystans kulturowy) są często współzależne, co utrudnia precyzyjne wyłonienie wpływu każdej z nich na decyzje związane z umiędzynarodowieniem. Zdaniem Rugmana i Verbeke (2004) charakter powiązań między różnymi kategoriami dystansu odzwierciedla regionalną naturę współczesnego handlu i inwestycji zagranicznych. Przykładowo, integracja gospodarcza na poziomie regionów sprzyja ujednoliceniu instytucji oraz redukcji dystansu kulturowego i ekonomicznego dzięki zwiększonej mobilności pracy i transferowi najlepszych praktyk menedżerskich. Jednocześnie dzięki wspólnej infrastrukturze transportowej oraz poprawie jakości i liczby połączeń (np. w ruchu lotniczym) osłabia ona wpływ dystansu geograficznego.

Spośród czterech wymiarów dystansu odnoszących się do „obiektywnych” (tj. mierzonych na poziomie kraju) różnic między rynkami dystans kulturowy cieszy się największym zainteresowaniem badaczy. Wysoka liczba badań nie prowadzi jednak do poszerzenia wiedzy o znaczeniu dystansu kulturowego w procesie umiędzynarodowienia przedsiębiorstw, regularnie przynosząc wykluczające się wyniki w odniesieniu do kierunku, sposobu i efektów internacjonalizacji. Wyjątkiem są badania ukazujące związek pomiędzy dystansem kulturowym a poziomem lokalnej adaptacji. Brak jednoznacznych wyników, które pozwoliłyby rozwijać teorie IB, przypisywany jest niedoskonałościom narzędzi pomiaru i bazowaniu na pracy Hofstede (Shenkar 2001). Dokonany przegląd literatury pozwala na sformułowanie kilku istotnych wniosków dla badaczy zainteresowanych tematyką dystansu w biznesie międzynarodowym. 
Tabela 2 | Powiązania między kluczowymi zagadnieniami internacjonalizacji przedsiębiorstw i dystansem

\begin{tabular}{|c|c|}
\hline Wymiary & Znaczenie dystansu w kluczowych zagadnieniach internacjonalizacji \\
\hline 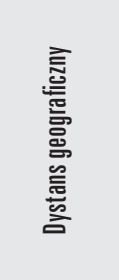 & $\begin{array}{l}\text { - Wybór kierunku umiędzynarodowienia: preferowanie rynków bliskich geograficznie (Dow 2000; Chetty 1999; Ojala, Tyrväinen } \\
\text { 2007; Boeh, Beamish 2012). } \\
\text { - Wybór formy umiędzynarodowienia - w przypadku duiego dystansu preferowaną formą jest wspólne przedsięwzięcie (Boeh, } \\
\text { - Beamish 2012). } \\
\text { - W teoriach grawitacyjnych dystans geograficzny jest zmienną ttumaczącą wartośćc wymiany handlowej między dwoma } \\
\text { krajami (Tinbergen 1962); większość wymiany handlowej odbywa się pomiędzy krajami połozionymi w niewielkiej odległości } \\
\text { od siebie. }\end{array}$ \\
\hline & 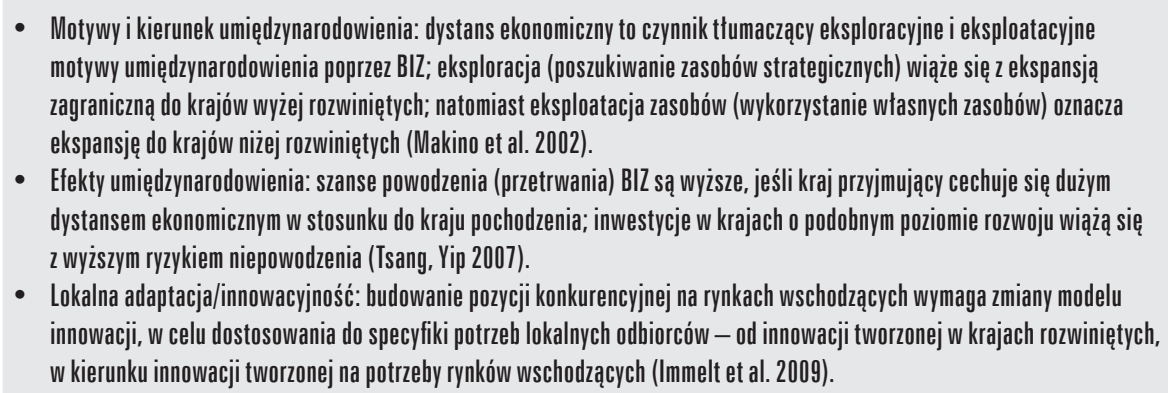 \\
\hline 邑 & $\begin{array}{l}\text { - Sposób wejścia na rynek zagraniczny: wzrost dystansu instytucjonalnego wiaże się z nizszzym udziałem kapitałowym w filiach } \\
\text { zagranicznych (Xu 2001; Ando 2012), przy czym firmy posiadające doświadczenie zagraniczne utrzymują relatywnie wyższe } \\
\text { udziały kapitałowe w filiach usytuowanych na instytucjonalnie odległych rynkach (Ando 2012). } \\
\text { - Globalna integracja działań / transfer wiedzy: dystans instytucjonalny utrudnia transfer zasad i praktyk biznesowych } \\
\text { z centrali do filii zagranicznych (Kostova, Zaheer 1999; Xu 2001; Ferner et al. 2005; Aguilera-Caracuel et al. 2012). }\end{array}$ \\
\hline & $\begin{array}{l}\text { - Wybór kierunku umiędzynarodowienia: dystans kulturowy (DK) nie jest istotnym czynnikiem uwzględnianym w podejmo- } \\
\text { waniu decyzji o wyborze rynku (Robertson, Wood 2001); DK wpływa na wybór obstugiwanych rynków (Edwards, Buckley } \\
\text { 1998). } \\
\text { - Sposób wejścia na rynek zagraniczny: w warunkach wysokiego poziomu DK firmy umiędzynarodawiają swoją działalność } \\
\text { w sposób: zapewniający pełną kontrolę (Padmanabhan, Cho 1996); Iub przeciwnie - w formie zapewniającej podział kontroli } \\
\text { i ryzyka (Brouthers, Brouthers 2001); bądí nie ma zależności między DK a preferowanym poziomem kontroli nad filią (Erra- } \\
\text { milli 1996). } \\
\text { - Efekty umiędzynarodowienia: trwałość spótek lokalizowanych za granicą jest odwrotnie związana z DK (Barkema et al. } \\
\text { 1996; Hennart, Zeng 2002); istnieje pozytywna zależność między DK a efektami (wzrostem przychodów) akwizycji (Morosini } \\
\text { et al. 1998); nie ma zależności między DK a wynikami finansowymi (Gomez-Mejia, Palich 1997). } \\
\text { - Lokalna adaptacja: Dystans kulturowy wiąże się z lokalnąa adaptacją strategii marketingowej w zakresie ceny, promocji } \\
\text { i produktu (Moon, Park 2011). }\end{array}$ \\
\hline 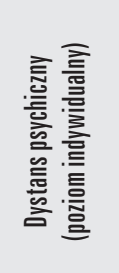 & $\begin{array}{l}\text { - Wybór kierunku umiędzynarodowienia: w początkowej fazie umiędzynarodowienia firmy wybierają rynki charakteryzujące się } \\
\text { niskim poziomem dystansu psychicznego (Johanson, Vahlne 1977). } \\
\text { - Efekty umiędzynarodowienia: niedocenianie dystansu psychicznego między pozornie bliskimi kulturowo krajami mozie } \\
\text { osłabiać wyniki umiędzynarodowionych przedsiębiorstw (O'Grady, Lane 1996), dystans psychiczny mozie, w sytuacji braku } \\
\text { wiedzy o rynku docelowym, sprzyjać osiąganiu lepszych wyników (Dikova 2009). } \\
\text { - Globalna integracja działań / transfer wiedzy: wysoki dystans psychiczny utrudnia transfer wiedzy w ramach korporacji } \\
\text { międzynarodowej (Pedersen et al. 2003). }\end{array}$ \\
\hline
\end{tabular}

Źródło: opracowanie własne. 
Po pierwsze, biorąc pod uwagę wielowymiarowość pojęcia dystansu oraz wysoką niejednoznaczność wyników prac empirycznych poświęconych wymiarowi kulturowemu, należy zachęcać badaczy do korzystania także z innych wymiarów dystansu, które mogą przynieść nowe spojrzenie na kluczowe zagadnienia internacjonalizacji. Na szerszą uwagę zasługują: dystans instytucjonalny, szczególnie w wymiarze regulacyjnym, oraz dystans ekonomiczny. W przypadku badania dystansu kulturowego warto rozważyć zastosowanie alternatywnych sposobów pomiaru, opartych nie na wymiarach Hofstede, lecz na wskaźnikach nawiązujących do aktualnego dorobku antropologii i psychologii międzykulturowej, np. projekt GLOBE, wymiary kultury Schwartza (1994) lub Trompenaarsa i Humpdena-Turnera (2007).

Po drugie, badania powinny uwzględniać wcześniejsze doświadczenia firm, ponieważ wpływ wymiarów dystansu nie ma charakteru absolutnego, lecz względny i ewoluujący, zależący od czynników kontekstualnych, takich jak doświadczenie firmy w procesie internacjonalizacji oraz doświadczenie na danym rynku (Berry et al. 2010).

Po trzecie, pomiar dystansu psychicznego w prawidłowy sposób, tj. na poziomie indywidualnym, otwiera stosunkowo nowe pole badawcze. $\mathrm{O}$ ile dystans kulturowy powinien być mierzony na poziomie kraju, o tyle dystans psychiczny jest konstruktem odnoszącym się do jednostki. Dystans psychiczny powodowany jest czynnikami zniekształcającymi przepływ informacji docierających do menedżerów, natomiast dystans kulturowy odnosi się do grup lub krajów (Sousa, Bradley 2006). Zasadność stosowania zindywidualizowanych miar wynika z faktu, iż w procesie umiędzynarodowienia menedżerowie podejmują decyzje na podstawie własnej percepcji otoczenia. Wyniki wcześniejszych prac sugerują, że percepcja dystansu kulturowego przez menedżerów lepiej tłumaczy zagadnienia internacjonalizacji niż stosowanie zewnętrznych miar (por. Dow 2000; Moon, Park 2011). W konstrukcie dystansu psychicznego należy także uwzględnić inne wymiary niż tylko kulturowy.

Podsumowując powyższe spostrzeżenia, należy stwierdzić, że przyszłe badania powinny ukazywać powiązania między różnymi typami dystansu, uwzględniając kilka wymiarów jednocześnie. Pozwoli to na określenie, czy i który z wymiarów dystansu mierzonych na poziomie różnic między krajami ma kluczowe znaczenie $\mathrm{w}$ danym kontekście gospodarczym. W odniesieniu do dystansu psychicznego, operacjonalizowanego na poziomie indywidualnym, niewątpliwie interesujące byłyby badania poświęcone mechanizmom redukcji niepewności wynikającej z dystansu.

Mimo postępującej integracji regionalnej i pewnej konwergencji kulturowej (Levitt 1983; Friedman 2006) Rugman (2005) uważa, że dystans między regionami wzrasta. Liczne przykłady firm, wycofujących się z rynków zagranicznych, sugerują, że niedocenianie - prawdopodobnie coraz bardziej subtelnych - różnic między rynkami może prowadzić do niepowodzenia. Analizując opcje wzrostu, z uwzględnieniem ekspansji zagranicznej, menedżerowie powinni wnikliwie przyjrzeć się poszczególnym wymiarom dystansu, bowiem zrozumienie wyzwań w poszczególnych obszarach zwiększa szanse na właściwy wybór rynku, sposobu wejścia i strategii działania na danym rynku zagranicznym. 


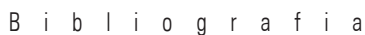

Aguilera-Caracuel J., Aragon-Correa J.A., Hurtado-Torres N.E., Rugman A. (2012) The effects of institutional distance and headquarters' financial performance on the generation of environmental standards in multinational companies. Journal of Business Ethics, Vol. 105, No. 4, s. 461-474.

Ali Y. (1995) Performance of international joint ventures (IJVS) in developing countries: A study of IJVs in Bangladesh. Niepublikowana praca doktorska, University of Wollongong, http://ro.uow.edu.au/theses/3089/.

Ando N. (2012) The ownership structure of foreign subsidiaries and the effect of institutional distance: a case study of Japanese firms. Asia Pacific Business Review, Vol. 18, No. 2, s. 259-274.

Barkema H., Bell J., Pennings J. (1996) Foreign Entry, Cultural Barriers and Learning. Strategic Management Journal, Vol. 17, No. 2, s. 151-166.

Bartlett C.A., Ghoshal S. (1989) Managing Across Borders: The Transnational Solution. Boston, MA: Harvard Business School Press.

Beckerman W. (1956) Distance and the pattern of intra-european trade. The Review of Economics and Statistics, Vol. 38, No. 1, s. 31-40.

Berry H., Guillén M.F., Zhou N. (2010) An institutional approach to cross-national distance. Journal of International Business Studies, Vol. 41, No. 9, s. 1460-1680.

Black J.S., Mendenhall M., Oddou G.R. (1991) Towards a comprehensive model of international adjustment: An integration of multiple theoretical perspectives. Academy of Management Review, Vol. 16, No. 2, s. 291-317.

Boeh K., Beamish P. (2012) Travel time and the liability of distance in foreign direct investment: Location choice and entry mode. Journal of International Business Studies, Vol. 43, No. 5, s. 525-535.

Boski P. (2009). Kulturowe ramy zachowań społecznych. Warszawa: Wydawnictwo Naukowe PWN.

Boyacigiller N. (1990) The role of expatriates in the management of interdependence, complexity and risk in multinational corporations. Journal of International Business Studies, Vol. 21, No. 3, s. 357-381.

Brock J., Johnson J.E., Zhou J. (2011) Does distance matter for internationally-oriented small firms? Industrial Marketing Management, Vol. 40, No. 3, s. 384-394.

Brouthers K., Brouthers L. (2001) Explaining the national cultural distance paradox. Journal of International Business Studies, Vol. 32, No. 1, s. 177-189.

Buckley P.J., Casson M. (1976) The future of the multinational enterprise. London: McMillan \& Co.

Cairncross F. (1997) The death of distance: How the communications revolution is changing our lives. Boston: Harvard Business School Press.

Carr D.L., Markusen J.R., Maskus K.E. (2001) Estimating the knowledge-capital model of the multinational enterprise. American Economic Review, Vol. 91, No. 3, s. 693-708.

Chetty S. (1999) Dimensions of Internationalisation of Manufacturing Firms in the Apparel Industry. European Journal of Marketing, Vol. 33, No. 1-2, s. 121-142.
Cieślik A. (2007) Wpływ porozumień o wolnym handlu na wielkość wymiany handlowej Polski w latach 1992-2004. Bank i Kredyt, czerwiec, s. 3-23.

Clark T., Pugh D.S. (2001) Foreign Country Priorities in the Internationalization Process: A Measure and an Exploratory Test on British Firms. International Business Review, Vol. 10, No. 3, s. 285-303.

Clark X., Dollar D., Micco A. (2004) Port efficiency, maritime transport costs, and bilateral trade. Journal of Development Economics, Vol. 75, No. 2, s. 417-450.

Cyert R.M., March J.G. (1963) A Behavioral Theory of the Firm. Englewood Cliffs, NJ.

Dow D. (2000) A Note on Psychological Distance and Export Market Selection. Journal of International Marketing, Vol. 8, No. 1, s. 51-64.

Dow D., Karunaratna A. (2006) Developing a multidimensional instrument to measure psychic distance stimuli. Journal of International Business Studies, Vol. 37, No. 5, s. 578-602.

Dikova D. (2009) Performance of foreign subsidiaries: does psychic distance matter? International Business Review, Vol. 18, No. 1, s. 38-49.

Edwards R.W., Buckley P.J. (1998) Choice of Location and Mode: The Case of Australian Investors in the U.K. International Business Review, Vol. 7, No. 5, s. 503-520.

Ellis P.D. (2007) Paths to foreign markets: does distance to market affect firm internationalisation? International Business Review, Vol. 16, No. 5, s. 573-593.

Eriksson K., Majkgard A., Sharma D. (2000) Path dependence and knowledge development in the internationalization process. Management International Review, Vol. 40, No. 4, s. 307-328.

Erramilli M.K. (1996) Nationality and subsidiary ownership patterns in multinational corporations. Journal of International Business, Vol. 27, No. 2, s. 225-248.

Evans J., Treadgold A., Mavondo F. (2000) Psychic distance and the performance of international retailers. A Suggested Theoretical Framework. International Marketing Review, Vol. 17, No. 4/5, s. 373-391.

Ferner A., Almond P., Colling T. (2005) Institutional Theory and the Cross-National Transfer of Employment Policy: The Case of Workforce Diversity in Us Multinationals. Journal of International Business Studies, Vol. 36, No. 3, s. 304-321.

Frankel J., Rose A. (2002) An estimate of the effect of common currencies on trade and income. Quarterly Journal of Economics, Vol. 117, No. 2, s. 437-466.

Friedman T. (2006) Świat jest płaski. Krótka historia XXI wieku, Poznań: Dom Wydawniczy Rebis.

Ghemawat P. (2001) Distance still matters: The hard reality of global expansion. Harvard Business Review, Vol. 79, No. 8, s. 137-147.

Gomez-Mejia L., Palich L. (1997) Cultural Diversity and the Performance of Multinational Firms. Journal of International Business Studies; Vol. 28, No. 2, s. 309-335.

Håkanson L., Ambos B. (2010) The antecedents of psychic distance. Journal of International Management, Vol. 16, No. 3, s. 195-210. 
Hamill J. (1997) The Internet and international marketing. International Marketing Review, Vol. 14, No. 5, s. 300-323.

Hennart J.F., Zeng M. (2002) Cross-cultural differences and joint venture longevity. Journal of International Business Studies, Vol. 33, No. 4, s. 699-716.

Hofstede G. (2007) Kultury i organizacje. Warszawa: PWE.

Hummels D. (2001) Time as a trade barrier. Working paper, Krannert School of Management, Purdue University, www. mgmt.purdue.edu/faculty/hummelsd/research/time3b.pdfS.

Hummels D., Lugovskyy V., Skiba A. (2007) The Trade Reducing Effects of Market Power in International Shipping. National Bureau of Economic Research Working Paper 12914.

Hummels D. (2007) Transportation costs and international trade in the second era of globalization. Journal of Economic Perspectives, Vol. 21, No. 3, s. 131-154.

Hymer S.H. (1976) The international operations of national firms: A study of direct foreign investment. Cambridge, MA: MIT Press.

Immelt J.R., Govindarajan V., Trimble C. (2009) How GE is Disrupting Itself? Harvard Business Review, Vol. 87, No. 10, s. $56-65$.

Johanson J., Vahlne J.-E. (1977) The internationalization process of the firm - a model of knowledge development and increasing foreign market commitments. Journal of International Business Studies, Vol. 8, No. 1, s. 23-32.

Johanson J., Wiedersheim-Paul F. (1975) The internationalization of the firm: four Swedish cases. Journal of Management Studies, Vol. 12, No. 3, s. 305-322.

Kaufmann D., Kraay A., Mastruzzi M. (2005) Governance matters IV: governance indicators for 1996-2004. World Bank policy research paper 3630.

Khanna T., Palepu K. (2010) Winning in emerging markets. Boston: Harvard Business Press.

Kogut B., Singh H. (1988) The Effect of National Culture on the Choice of Entry Mode. Journal of International Business Studies, Vol. 19, No. 3, s. 411-432.

Kostova T., Zaheer S. (1999) Organizational Legitimacy under Conditions of Complexity: The Case of the Multinational Enterprise. Academy of Management Review, Vol. 24, No. 1, s. 64-81.

Lankhuizen M., de Groot H.L.F., Linders G-J.M. (2011) The Trade-Off between Foreign Direct Investments and Exports: The Role of Multiple Dimensions of Distance, The World Economy, Vol. 34, No. 8, s. 1395-1416.

Levitt T. (1983) The Globalization of Markets. Harvard Business Review, Vol. 61, No. 3, s. 92-102.

Linmao N., Venables A.J. (2001) Infrastructure, geographical disadvantage, transport costs, and trade. The World Bank Economic Review, 15(3): 451-479.

Makino S., Lau C.-M., Yeh R.-S. (2002) Asset-exploitation versus asset-seeking: Implications for location choice of foreign direct investment from newly industrialized economies. Journal of International Business Studies, Vol. 33, No. 3, s. 403-421.

March J.G. (1991) Exploration and exploitation in organizational learning. Organization Science, Vol. 2, No. 1, s. 71-87.
Moon T.W., Park S.II. (2011) The Effect of Cultural Distance on International Marketing Strategy: A Comparison of Cultural Distance and Managerial Perception Measures. Journal of Global Marketing, Vol. 24, No. 1, s. 18-40.

Morosini P., Shane S., Singh H. (1998) National Cultural Distance and Cross-Border Acquisition Performance. Journal of International Business Studies, Vol. 29, No. 1, s. 137-158.

Nordström K.A., Vahlne J.E. (1994) Is the globe shrinking? Psychic distance and the establishment of Swedish sales subsidiaries during the last 100 years. W: Landeck M. (red.), International Trade: Regional and Global Issues. St Martin's Press.

O'Grady S., Lane H. (1996) The psychic distance paradox. Journal of International Business Studies, Vol. 27, No. 2, s. 309-333.

Ojala A., Tyrväinen P. (2007) Market Entry and Priority of Small and Medium-Sized Enterprises in the Software Industry: An Empirical Analysis of Cultural Distance, Geographic Distance, and Market Size. Journal of International Marketing, Vol. 15, No. 3, s. 123-149.

Padmanabhan P., Cho K.R. (1996) Ownership strategy for a foreign affiliate: An empirical investigation of Japanese firms. Management International Review, Vol. 36, No. 1, s. $45-65$.

Pedersen T., Petersen B., Sharma D. (2003) Knowledge Transfer Performance of Multinational Companies. Management International Review, Vol. 43, No. 3, s. 69-90.

Posner M. (1961) International trade and technical change. Oxford Economic Papers, Vol. 13, No. 3, s. 323-341.

Rao A., Schmidt S.M. (1998) A behavioral perspective on negotiating international alliances. Journal of International Business Studies, Vol. 29, No. 4, s. 665-694.

Robertson K.R., Wood V. (2001) The Relative Importance of Type of Information in the Foreign Market Selection Process. International Business Review, Vol. 10, No. 3, s. 363-379.

Rosenzweig P.M., Nohira N. (1994) Influences on human resource management practices in multinational corporations. Journal of International Business Studies, Vol. 25, No. 3, s. 229-251.

Rugman A.M. (2005) The Regional Multinationals: MNEs and 'Global' Strategic Management. Cambridge: Cambridge University Press.

Rugman A.M., Verbeke A. (2004) A perspective on regional and global strategies of multinational enterprises, Journal of International Business Studies, Vol. 35, No. 1, s. 3-18.

Schwartz S.H. (1994) Beyond individualism/collectivism: New dimensions of values. Thousand Oaks, CA: Sage.

Scott W.R. (1995) Institutions and Organizations: Theory and Research. Thousand Oaks, CA: Sage.

Shenkar O. (2001) Cultural distance revisited: towards a more rigorous conceptualization and measurement of cultural differences. Journal of International Business Studies, Vol. 32, No. 3, s. 519-535.

Simon H.A. (1947/1997) Administrative Behavior: a Study of Decision-Making Processes in Administrative Organizations. New York: The Free Press. 
Sousa C., Bradley F. (2006) Cultural Distance and Psychic Distance: Two Peas in a Pod? Journal of International Marketing, Vol. 14, No. 1, s. 49-70.

Xu D. (2001) The effect of institutional distance on multinational enterprise strategy. Niepublikowana praca doktorska, [http:// en.scientificcommons.org/50562464] York University, Toronto.

Terpstra V., Chwo-Ming Y. (1988) Determinants of Foreign Investment of U.S. Advertising Agencies. Journal of International Business Studies, Vol. 19, No. 1, s. 33-46.

Tinbergen J. (1962) Shaping the world economy: suggestions for an international economic policy. New York.

Tsang E., Yip P. (2007) Economic distance and the survival of foreign direct investment. Academy of Management Journal, Vol. 50, No. 5, s. 1156-1168.
Trompenaars F., Hampden-Turner C. (2007) Siedem wymiarów kultury. Kraków: Oficyna Ekonomiczna.

Vernon R. (1966) International investment and international trade in the product cycle. Quarterly Journal of Economics, Vol. 80, No. 2, s. 190-207.

Williamson O. (1998) Ekonomiczne instytucje kapitalizmu. Warszawa: Wydawnictwo Naukowe PWN.

Wolniak R. (2011) Czynniki kulturowe w polskich organizacjach. Przegląd Organizacji, nr 11, s. 18-20.

Zhao H., Luo Y., Suh T. (2004) Transaction cost determinants and ownership-based entry mode choice: a meta-analytical review. Journal of International Business Studies, Vol. 35, No. 6, s. 524-544. 